\title{
Purification of Rabies Soluble Antigens
}

\author{
BY T. H. MEAD \\ The C.S.I.R. and U.C.T. Virus Research Unit, Department of Pathology, \\ University of Cape Town, South Africa
}

(Received 28 April 1961)

\begin{abstract}
SUMMARY
The ability of extracts of rabies-infected suckling mouse brains, freed from virus by centrifugation, to fix complement in the presence of mouse antirabies serum was confirmed. The complement-fixing (CF) activity, which was unstable, was partially purified by precipitation, solvent treatment, adsorption, chromatography and electrophoresis. There appeared to be constituents of normal brain which closely resembled the CF activity in their behaviour towards these treatments. Descriptions are given: of $(a)$ a device for stepwise elution of chromatograph columns; $(b)$ modifications to the LKB Produkter electrophoresis apparatus to ensure constant electrical resistance; $(c)$ a method for estimating 'protein' which is useful when the ultra-violet (u.v.) radiation method is inapplicable.
\end{abstract}

\section{INTRODUCTION}

It was shown by Polson \& Wessels (1953) that extracts of rabies-infected suckling mouse brains contained in addition to the virus (which could be removed by centrifugation) a smaller specific component which was demonstrable by complementfixation tests. Much additional information about the antigen was published by Van den Ende, Polson \& Turner (1957). The original objects of the work now presented were to purify this small component, to compare it with the intact virus and to attempt to determine whether it was a subunit of the virus particle or merely a by-product of infection.

\section{METHODS}

Virus. The history of the egg-adapted Flury strain of virus was described by Van den Ende et al. (1957). Material from the seventeenth passage in suckling mouse brain was freeze-dried and used as reference stock. From this, working stocks were prepared at intervals and kept at $-70^{\circ}$. The total number of passages did not exceed 20. In May 1960 it was confirmed that the current working stock virus (LD50 $=10^{-5} \cdot 0 / 0.02 \mathrm{ml}$. intracerebrally in mice) was completely neutralized (LD $50<10$ ) by a rabbit anti-rabies serum prepared in Johannesburg by the South African Institute for Medical Research.

Mouse anti-rabies sera. Adult mice in batches of about 200 received $10-130 \cdot 2 \mathrm{ml}$. intraperitoneal injections of a $10 \%(\mathrm{v} / \mathrm{v})$ emulsion of freshly infected suckling mouse brains at 3- to 4-day intervals. Usually, in the preparation of batches VII and IX, for example, only the first dose was inactivated with formalin (0.35\%). Serum VIII which later proved to differ perceptibly from other batches was pre- 
pared by immunization with formalin-inactivated virus throughout. Mice were bled 7-10 days after the last injection. The serum was inactivated at $56^{\circ}$ for at least 30 min., clarified by centrifugation at $59,000 \mathrm{~g}$ for $1 \mathrm{hr}$. under liquid paraffin (which assisted the removal of lipids) and stored at $4^{\circ}$ after treatment with thiomersalate.

Normal mouse antiserum was similarly prepared by inoculating a suspension of uninfected suckling mouse brains into adult mice.

Trypsin which had been crystallized at least twice was the generous gift of Seravac Laboratories, Cape Town. Some batches were salt free, others contained about $30 \%$ of magnesium sulphate.

Complement-fixing titrations were carried out generally as described by Casals \& Olitsky (1950) but non-serial logarithmic dilutions covering a range of $1 \mathrm{log}$ in 10 steps were used instead of serial twofold dilutions for all but the less exact experiments. The smoothness of the curves obtained by plotting the CF titres of successive fractions from chromatography and electrophoresis appeared to justify the assumption that differences of $0.2 \log (1.58$ fold) obtained in one test were probably significant. When results obtained on one day were to be compared with those found on another, a standard batch of freeze-dried extract was titrated on both occasions and the results were corrected for any discrepancy between the titres of the standard. The diluent for the antigen (CFT saline) was the veronal-buffered saline containing $\mathrm{Mg}$ and $\mathrm{Ca}$ recommended by Mayer, Osler, Bier \& Heidelberger (1946).

Chemicals. Reagents were of the best quality available and solvents were redistilled through a column. All water was distilled in glass. 1:2-Difluorotetrachloroethane (Freon 112) was a gift from E. I. du Pont de Nemours and Co. Difco agar was treated by the method of Dulbecco \& Vogt (1954).

Buffered saline (BS), $0.85 \%(\mathrm{w} / \mathrm{v}) \mathrm{NaCl}, 0.01 \mathrm{~m}$-phosphate ( $\mathrm{pH} \mathrm{7}$ ); $\mathrm{pH} 8.4$ saline, $0.85 \%(\mathrm{w} / \mathrm{v}) \mathrm{NaCl}, 0.02 \mathrm{M}-\mathrm{Na}_{2} \mathrm{HPO}_{4}$ adjusted to $\mathrm{pH} 8 \cdot 4$ with $0 \cdot 2 \mathrm{M}-\mathrm{KH}_{2} \mathrm{PO}_{4}$.

EDTA saline, $\mathrm{NaCl} 17 \mathrm{~g}$., disodium ethylenediaminetetra-acetate (EDTA) $7 \cdot 4$ g., $0 \cdot 2 \mathrm{M}-\mathrm{Na}_{2} \mathrm{HPO}_{4} 63 \mathrm{ml}$., 'Triton X-100' (Rohm and Haas Co.) 0.2 g. thiomersalate 0.2 g., $2 \mathrm{~N}-\mathrm{NaOH}$ to $\mathrm{pH} 7.0$ in 2 l. All other buffers contained 'Triton X-100' $0.01 \%(\mathrm{w} / \mathrm{v})$ and thiomersalate $0.01 \%(\mathrm{w} / \mathrm{v})$.

Centrifugation at values exceeding $4000 \mathrm{~g}$ was carried out in models $\mathrm{L}$ or $\mathrm{LH}$ Spinco centrifuge. The forces quoted are average values calculated at the central point of the liquid column. For lower forces an MSE refrigerated centrifuge was used.

Methods of concentration. Pervaporation with intermittent dialysis against thiomersalate water followed by freeze-drying in ampoules was usually used. Prolonged dialysis (for more than 24-36 hr.) caused precipitation and was avoided. Pervaporation after being started in a current of warm air was sometimes continued overnight by placing the cellulose sac on a Petri dish under the cooling element of the refrigerator. In the morning the ice surrounding the sac and the small frozen residue inside were allowed to melt undisturbed to avoid cutting the cellulose. In some experiments dialysis against polyethylene glycol (Kohn, 1959) was used, but occasionally the low molecular weight (6000) glycol locally available passed through the membrane. The tendency of parts of the solution to dry on the sac and the difficulty in bringing the residue to a very small known volume (usually $\mathbf{0 . 0 5} \mathrm{ml}$. for Ouchterlony tests) were disadvantages of this method, for our purposes.

Comminution of brains was done at about 14,000 rev./min. in a 'top drive' blender 
in which all parts including the ball bearings were of stainless steel, enabling autoclaving to be carried out without the formation of rust.

Total nitrogen was determined by micro-Kjeldahl with the mercury catalyst and digestion conditions of McKenzie \& Wallace (1954).

Estimation of 'protein'. In some early experiments total dry residue (after dialysis) or total nitrogen were used as guides to the concentration of substances (mostly impurity) in experimental solutions. As the number of samples increased and their concentration diminished, alternative methods were tested. Because of uncertainties in u.v. absorption measurements and insensitivity of other methods, 'protein' was determined by measuring the light scattered by the precipitate formed in very dilute protein solutions by the addition of perchloric acid. All observations made by the method will therefore be referred to as estimates of 'protein' with exclusion of such non-precipitable mucoproteins as may have been present. The method was: to $1 \mathrm{ml}$. of solution diluted to contain about $0 \cdot 05-0 \cdot 2 \mathrm{mg}$. protein $/ \mathrm{ml}$. was added $3 \mathrm{ml}$. of dilute (about $8 \%, \mathrm{w} / \mathrm{v})$ perchloric acid $(43.3 \mathrm{ml}$. A.R. $60 \%, \mathrm{w} / \mathrm{w}$, acid diluted to $500 \mathrm{ml}$.). A blank was set up at the same time and also a standard consisting of $1 \mathrm{ml}$. of a 1/1000 dilution of human serum in thiomersalate saline. This standard was kept at $4^{\circ}$ and used throughout and on the assumption that it contained about $0.07 \mathrm{mg} . / \mathrm{ml}$. of protein rough correlation with actual protein content could be made. Light scattering reached a maximum in $10 \mathrm{~min}$. and remained constant for at least 30 min. Measurements were made in a dark room with an apparatus based on that of Oster (1950). Unfiltered light from a $125 \mathrm{~W}$ mercury lamp, rendered parallel by a condenser and collimated by two vertical rectangular slits, entered one side of a rectangular Perspex cell internally $1 \mathrm{~cm} . \times 1 \mathrm{~cm}$. The photomultiplier cell used as detector was supported at right angles to the incident beam in a housing having two vertical slits $8 \mathrm{~cm}$. apart, excluding all but a narrow beam entering from the centre of the Perspex cell. Two adjacent sides of the cell were clear and two black. A square depression in the cell support ensured accurate placement. The output from the photocell was measured by a Cambridge 'spot' galvanometer ( $475 \Omega$, deflexion 125 scale divisions $/ \mu \mathrm{A}$.) with a potentiometer for varying the sensitivity. The batteries and galvanometer rested on 'Perspex' insulators and an extension handle of the same material was fitted to the zero adjuster. In use, the galvanometer was set to zero with the blank cell in position and (using the sensitivity control) to $\mathbf{1 9 \cdot 2}$ divisions with the standard and these two mutually dependent adjustments were repeated as required. The cell containing the experimental solution was then inserted and the galvanometer reading recorded. In any series of observations the zero point with the blank was checked between every measurement. The lamp was supplied from a constantvoltage transformer but mains voltage fluctuations were sometimes perceptible in spite of this precaution. 'Protein' estimates quoted in this paper are the galvanometer readings obtained when $1 \mathrm{ml}$. of the given dilution was treated with $3 \mathrm{ml}$. of the perchloric acid solution. Tests made with dilutions of crude and purified mouse brain extracts showed that the relation between concentration and deflexion was linear between 2 and 100 on the galvanometer scale.

Chromatography. Calcium phosphate suspension (brushite and hydroxyapatite) were prepared as described by Tiselius (1954) and Tiselius, Hjertén \& Levin (1956). Diethylaminoethylcellulose (DEAE cellulose) and carboxymethylcellulose (CM 
cellulose) were prepared according to Peterson \& Sober (1956). Triethylaminoethylcellulose (TEAE cellulose) was prepared from DEAE cellulose by the method of Porath (1957).

Stepwise elution, when continued overnight, was by buffers layered over one another

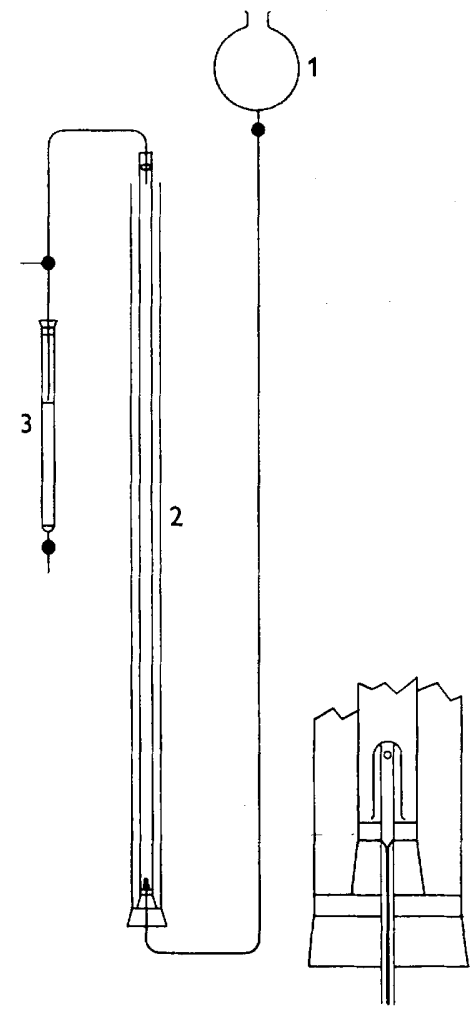

Fig. 1

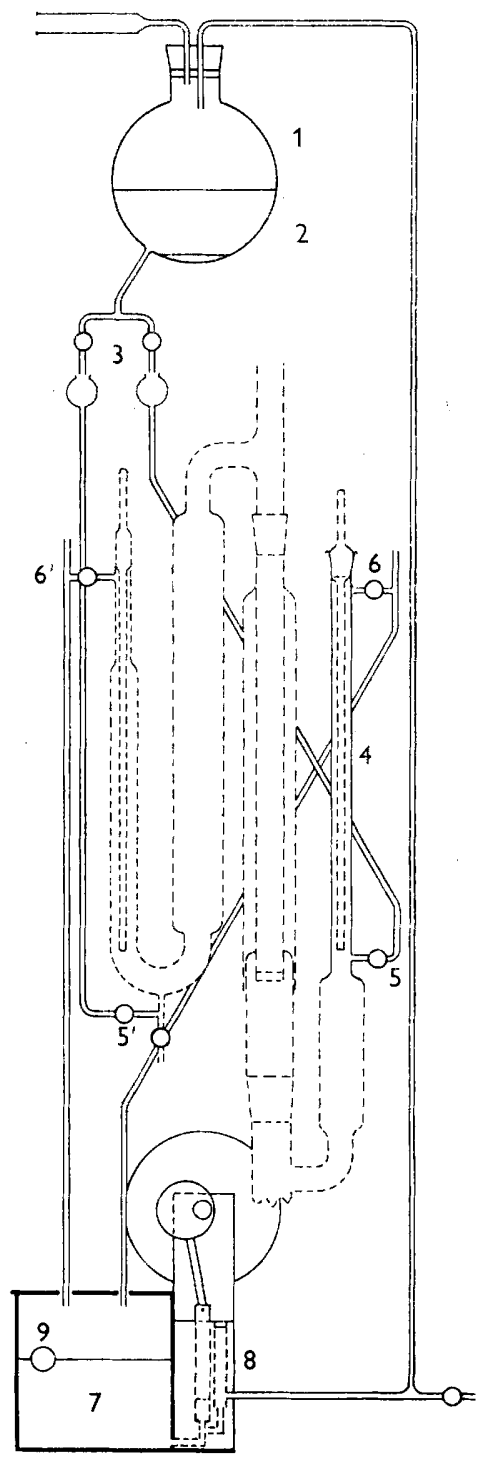

Fig. 2

Fig. 1. Apparatus for stepwise elution. 1, separating funnel; 2, reservoir; 3, column. Connexions are of narrow bore tube. Inset shows, on a larger scale, the baffle preventing the formation of eddies in the reservoir.

Fig. 2. Buffer circulation system for the L.K.B.-Produkter column electrophoresis apparatus. Broken lines show parts of the original apparatus. Full lines show the modifications. 1, upper reservoir; 2, chloroform to maintain sterility; 3 , drip feeds; 4 , narrowed anode vessel; $5,5^{\prime}$, buffer inlets to electrode vessels; $6,6^{\prime}$, buffer exits with antisiphoning tees; 7, lower reservoir; 8, 'Perspex' pump; 9, float controlling pump. 
in a tall, narrow, vertical tube surrounded by a jacket of static watcr to hinder convection and connected as shown in Fig. 1. The buffers were introduced through the separating funnel, starting with the most dilute, while air escaped through the tap. The funnel was eventually filled with enough of a solution denser than the most concentrated buffer, to displace the contents of the reservoir. In spite of inevitable diffusion at the interfaces, the elution diagrams had the pronounced peaks characteristic of stepwise elution. Linear gradients used in all the later experiments were prepared in apparatus based on the principle of Parr (1954). The fraction collectors were of the siphon balance type.

Electrophoresis. (a) In starch gel. The Smithies (1955) technique was used. The walls of the trough were in two sections assembled sandwichwise to facilitate horizontal slicing of the gel before staining. (b) On paper and glass fibre sheets. The apparatus of Flynn \& de Mayo (1951) was used. (c) On cellulose acetate strips. The strips (Kohn, 1957) were supported on cooled glass (made water-repellent with dimethyldichlorosilane) in a closed apparatus. (d) Immunoelectrophoresis and electrophoresis in agar. The macro- and micro-methods of Grabar $\&$ Williams (1955) and of Scheidegger (1955) were used. In some experiments the thin glass plates supporting the agar slabs were placed in the closed apparatus used for starch grain electrophoresis (below) and cooled by the circulation of refrigerated water. Thermal contact between the glass and the Perspex floor of the apparatus was improved by a thin layer of $0.5 \%$ aqueous agar. In this way gradients up to $16 \mathrm{~V} . / \mathrm{cm}$. in the gel could be used without appreciable evaporation. Agar clectrophoretograms were usually fixed with ethanolic acetic acid containing $\mathrm{HgCl}_{2}(0 \cdot 4 \%$, w/v) and stained with naphthalenc black (Uriel \& Grabar, 1956). Immunoelectrophoretograms after being washed with thiomersalate saline for at least $\mathbf{B}$ days were usually subjected to contact printing both before and after being stained (without prior dying) with nigrosine $(0.002 \%, \mathrm{w} / \mathrm{v})$ in $2 \%(\mathrm{v} / \mathrm{v})$ acetic acid (Kohn 1958). (e) Starch grairs. The technique and water-cooled apparatus of Paigen (1956) were used. The dimensions of the slab were $30 \mathrm{~cm} . \times 8 \mathrm{~cm} . \times$ about $0.5 \mathrm{~cm}$. ( $f$ ) In a column of modified cellulose. The column filling was prepared as described by Flodin \& Kupke (1956). In using the LKB-Produkter column electrophoresis apparatus it was found that the resistance increased considerably during extended runs and it was suspected that much of this increase occurred at the clectrodes and was accompanied by a decreased potential gradient in the separation zone. The apparatus was therefore modified (Fig. 2) to permit a continuous flow of recirculated buffer over the electrodes. The resistance of the modified apparatus remained constant for at least $24 \mathrm{hr}$.

Gel precipitin tests. Scarcity of antigen and antiserum restricted most testing to the micro-Ouchterlony method. After experiments with various buffers, $0.85 \%$ $(w / v)$ saline was used as solvent for the agar $(1 \%, w / v)$. For most tests a cutter was used to give a hexagonal arrangement of $2 \mathrm{~mm}$. diameter wells with centres $5 \mathrm{~mm}$. apart ('narrow spacing'). Occasionally patterns of similar holes with centres $7 \cdot \mathbf{5}$ or $10 \mathrm{~mm}$. apart were used ("wide spacing'). The plates were sometimes used for contact printing before they were washed and stained. Washing in thiomersalate saline was continued for at least 3 days but frequently failed to remove all residual unprecipitated protein. 'The plates were usually stained in the swollen state with $0.002 \%(\mathrm{w} / \mathrm{v})$ nigrosine in $2 \%(\mathrm{w} / \mathrm{v})$ acetic acid. In some experiments duplicate plates were washed, dried and stained with naphthalene black (Criel \& Grabar, 
1956) but this more complicated technique did not offer any special advantage. 'The main difficulties were the complete removal of irrelevant protein before staining and the photographic reproduction of the lines, often very faint.

Ertraction of antigens. The brains from suckling mice dead or moribund 3-4 days after intracerebral infection with virus, were stored, when necessary, for short periods at $-20^{\circ}$ and extracted in batches of about 200 by one of the methods described below. The Casals (1949) method, modified to include extraction of the macerated brains with chloroform + methanol as well as acetone + ether, was used for most of the early experiments. Plain saline extraction was used later. When an ultrasonic disintegrator became available saline extraction by using this instrument was used. The following experiment ('Table 1) made to compare the three methods, illustrates the procedures. The frozen brains from 529 infected

'Table 1. Properties of crude extracts obtained by three methods from one batch of brains

\begin{tabular}{|c|c|c|c|c|c|c|}
\hline Batch & Preparation & $\begin{array}{l}\text { Volume } \\
\text { (ml.) }\end{array}$ & CFI* & $\begin{array}{c}\text { 'Protein' } \\
\text { (undiluted) } \dagger\end{array}$ & $\begin{array}{l}\text { Purity } \\
\text { CFTy } \\
\text { protein, }\end{array}$ & $\begin{array}{c}\text { Yicld } \\
\text { vol. } \times \text { CFT }\end{array}$ \\
\hline $65: 1$ & Saline extract & $: 300$ & 285 & 450 & $0 \cdot 6: 3$ & $8 \mp, 000$ \\
\hline $6.5 / 2$ & $\begin{array}{l}\text { Saline with ultra- } \\
\text { sonic disintegra- } \\
\text { tion }\end{array}$ & $3(\%)$ & 500 & 425 & $1 \cdot 18$ & $150,(100$ \\
\hline $65 / 3$ & Modified Casals & 100 & $69)$ & 1000 & 0.69 & 69,000 \\
\hline
\end{tabular}

suckling mice were divided into three equal portions of $33.5 \mathrm{~g}$. One portion (batch $65 / 1$ ) was macerated (for a total time of 2 min. at about 14,000 rev. $/ \mathrm{min}$.) with a mixture of thiomersalate treated and cooled BS $(22.5 \mathrm{ml}$.) and crushed ice (from distilled water, $75 \mathrm{~g}$.). The mixture was centrifuged in the No. 30 rotor for $2 \mathrm{hr}$. at $44,000 \mathrm{~g}$ with refrigeration. The clear supernatant fluid formed the crude extract. Another portion (65/2) of the same batch of brains was maccrated with BS and ice in the same way but before bcing centrifuged the mixture was submitted, in portions of $25 \mathrm{ml}$, to the maximum output at $20 \mathrm{Kcyc}$. $/ \mathrm{sec}$. from an MSF-Mullard ultrasonic generator with a probe uniformly ${ }_{4}^{3}$ in. in diameter. Fach portion was treated for 5 min. The main bulk of the mixture and the portion under treatment were surrounded by ice. The crude extract was obtained by centrifugation at $44,000 \mathrm{~g}$ for $2 \mathrm{hr}$. The third portion (65/3) was maccrated for $2 \mathrm{~min}$. in acetone ( $400 \mathrm{ml}$.) which had been precooled in the apparatus to $-10^{\circ}$. The mixture was centrifuged with refrigeration at $580 \mathrm{~g}$. The supernatant fluid was discarded and the sediment extracted successively with acetone $(800 \mathrm{ml}$.) acetone +ether $(1: 1,400 \mathrm{ml}$.) then twice with chloroform + methanol $(3: 1,300 \mathrm{ml}$. each time) and finally twice with ether using $400 \mathrm{ml}$. for the penultimate and $200 \mathrm{ml}$. for the final treatment. Each extraction was carried ont ncar $4^{\circ}$ by intermittent shaking followed by centrifugation. After removal of ether under diminished pressure, the powder $(2 \cdot 78 \mathrm{~g}$. was stirred at about $4^{\circ}$ with $B S(40 \mathrm{ml}$.) containing 'Triton X-100 $(0.01 \%, \mathrm{w} / \mathrm{v})$ and thiomersalate $(0.01 \%, \mathrm{w} / \mathrm{v})$ for $30 \mathrm{~min}$. The mixture was centrifuged, the supernatant fluid removed and the residuc extracted twice more in the same way. The 
supernatant fluids were combined and, after being centrifuged at $59,000 \mathrm{~g}$ in the No. 40 rotor for $1 \mathrm{hr}$., formed the crude extract. The Casals procedure did not seem specially advantageous but sonic disintegration appeared to increase the yield of antigen without introducing extra protein. 'The purities (CF titre/" protein ' reading $\times$ dilution factor) of different batches (more than 60 have been used) varied from about $0 \cdot 14$ to $0 \cdot 6$. 'The value $1 \cdot 18$ for $65 / 2$ was exceptionally high. The extracts from this particular experiment were at once purified by the acid precipitation process to be described. When not required immediately, however, crude extracts were dialysed against EDTA saline, pervaporated, dialysed against water and freezedried in ampoules. All extracts received, during the course of purification, two centrifugations (at $44,000 \mathrm{~g}$ in No. 30 rotor for $2 \mathrm{hr}$. or $59,000 \mathrm{~g}$ in No. 40 rotor for I hr.), either of which had been found by infectivity testing to remove at least $99.99 \%$ of virus infectivity.

Attempts at stabilization. CF activity was unstable at $4^{\circ}$ and during concentration and purification procedures. There was no loss of activity in samples stored at $4^{\circ}$ after frecze-drying; and reduced loss after acid precipitation. Attempts were made to stabilize activity by addition of $\mathrm{Ca}$ and $\mathbf{M g}$ ions. Extracts were also dialysed against buffer containing EDTA to remove traces of heavy metals. No convincing evidence was obtained for the stabilizing effect of any of these procedures but, owing to a suggestion of improvement, dialysis against EITA buffer was retained as a normal step in the extraction procedurc. 'Triton X-100' $(0 \cdot 01 \%, \mathrm{w} / \mathrm{v})$ was added to nearly all buffers and solutions because it eliminated the surface denaturation easily visible when a foam was allowed to appear on the extracts and also because its wetting action improved the performance of fraction collectors. Tests made to corrclate foam-derived surface denaturation with loss of CF activity gave negative results.

\section{RESUI.TS}

When the presence of more than one antigen was not suspected, complementfixing (CF) activity alone was used as a measure of antigen content and attempts were made to concentrate and purify the extracts in terms of CF titre. Attempts to separate the individual antigens are described separately (Mcad, 1962).

\section{Dialysis precipitation}

A precipitate which formed during prolonged (at least $36 \mathrm{hr}$.) dialysis of crude extracts against water at $4^{\circ}$ (or more rapidly during clectrodialysis) carried down most of the CF activity. Of this about $30 \%$ was recoverable at two to three times the original purity by extracting the precipitate with BS. Dialysis precipitation was used as a preliminary purification step in several early experiments but was superseded by acid precipitation. A precipitate which carried down part of the CF activity also formed in crude extracts kept at $37^{\circ}$ but attempts to use this for purification were not successful.

\section{Acid precipitation}

This method was applied to extracts of infected egg membranes by Schäfer \& Munk (1952) and in a different manner to mouse brain extracts by Van den Ende et al. (1957). The distribution of CF activity and total $N$ after application of the 
original method to rabies infected mouse brain extracts is illustrated by the following example. A crude extract (57 ml., CF titre $1590 ; 2.63 \mathrm{mg} . \mathrm{N} / \mathrm{ml}$.) prepared by Casals method from 120 infected mouse brains was cooled to $4^{\circ}$ in a vessel surrounded by ice and provided with a mechanical stirrer and pII meter clectrodes. With the temperature adjustment on the meter set at the lower limit of $10^{\circ}$, the reading was adjusted to pH 4.5 by the slow addition of $0.1 \mathrm{~N}-\mathrm{IICl}$ (ahout $16 \mathrm{ml}$.). The suspension remained in ice for $20 \mathrm{~min}$. and was centrifuged for $40 \mathrm{~min}$. at $6600 \mathrm{~g}$ in the No. 40 rotor with refrigeration. (Later, delay at this stage was avoided.) The supernatant fluid was removed and the precipitate suspended in $\mathrm{pH} 8.4$ saline $(15 \mathrm{ml}$.). (When the supernatant was to be retained it was neutralized at once with $\mathrm{Na}_{2} \mathrm{HPO}_{4}$ ). After a night at $4^{\circ}$ the suspension was centrifuged at $6600 \mathrm{~g}$ for $30 \mathrm{~min}$. The supcrnatant fluid was removed, and the residue extracted twice more with 10 and $5 \mathrm{ml}$. amounts of $\mathrm{pH} 8.4$ saline, being stirred with the solvent for $1 \mathrm{hr}$. on each occasion. The three acid-precipitation purified (APP) extracts were combined and the pII 4.5 supernatant fluid and the undissolved residue were sampled for analysis. The AP' extract (29 ml.; CF titre $916 ; 0.52 \mathrm{mg} . \mathrm{N} / \mathrm{ml}$.) contained $29 \%$ of the original CF activity with a purity (in terms of total $\mathbf{N}$ ) $\mathbf{2} \cdot \mathbf{9}$ times that of the crude extract. Of the nitrogen in the crude extract $49 \%$ remained in the pH 4.5 supernatant, $39 \%$ in the residue isoluble at $\mathrm{pH} 8.4$ and $10 \%$ in the APP extract. The CF activity of the (neutralized) $\mathrm{pH} 4.5$ supcrnatant solution was usually about $5 \%$ of that of the crude extract, and such supernatants were discarded. When, however, the three crude extracts $65 / 1,65 / 2$ and $65 / 3$ described above were refined in this way the recoveries of $\mathrm{CF}$ activity in the supernatant fluids were respectively 34,25 and $23 \%$.

APP extracts were usually dialysed against EDTA salinc, centrifuged $1 \mathrm{hr}$. at $59,000 \mathrm{~g}$ in the $\mathrm{No} .40$ rotor (unless the crude extract had received two equivalent centrifugations), dialysed against water and freeze-dried unless required for immediate use. In contrast to the complete recovery of fowl plague soluble antigen from egg membrane extracts achieved by Schäfer \& Munk (1952), the recovery of rabies antigens was usually about $30 \%$. APP extracts, however, appeared to be more stable than crude extracts and nearly all the better results were obtained with them.

\section{Treatment with organic solvents}

Fmulsification of extracts, crude or APP, with chloroform (van den Ende t al. 1957) ether or difluorotetrachloroethane rcmoved all or most of the antigen from the aqueous layer. Part was recoverable with enhanced purity from the emulsion. After emulsification with butanol, however, appreciable activity remained in the aqueous layer. Of these solvents ether appeared to give the best results.

Ether. The freeze-dried residue from $15 \mathrm{ml}$. APP extract was dissolved in $15 \mathrm{ml}$. BS containing 'Triton X-100' $(0.01 \%, w / v)$ and thiomersalate $(0.01 \%, w / v)$. A $0.2 \mathrm{ml}$. sample (A) was diluted $1 / 20$ for analysis and the remainder cooled in solid $\mathrm{CO}_{2}+$ acetone mixture until ice began to separate. Intermittent cooling was continued while the solution was shaken vigorously for 10 min. with freshly distilled cther $(15 \mathrm{ml}$.). The mixture was centrifuged in the cold and the lower layer removed and treated twice more with ether $(15 \mathrm{ml}$.) in the same way. The final aqueous layer was partially freed from ether under reduced pressure and a $0.2 \mathrm{ml}$. sample 
(B) was diluted $1 / 20$ in BS for analysis. The gels from the upper phases (that from the third operation being very small) were united with the aid of about $5 \mathrm{ml}$. of BS and partially freed from ether under reduced pressure leaving a suspension which was dialysed against $B S$ overnight. The suspension was centrifugred $30 \mathrm{~min}$. at $59,000 \mathrm{~g}$ in the No. 40 rotor, the supernatant fluid removed and the residue suspended in $75 \mathrm{ml}$. of $\mathrm{BS}$ and centrifuged as before. The combined supernatant fluids werc diluted to $15 \mathrm{ml}$. and a $0.2 \mathrm{ml}$. sample (C) diluted $1 / 20$ with BS. The u.v. absorption curves of the three samples were plotted from 230 to $300 \mathrm{~m} \mu$ (with an appropriate blank) and 'protein' estimated as already described. The recovery of CF activity was $27 \%$ with a threefold increase in purity hased on 'protein' (Table 2). Although all samples absorbed maximally at or near $260 \mathrm{~m} \mu$ the absorption of the product at this wavelength was only $13 \%$ of that of the starting solution, suggesting that nuclcotides as well as 'protein' are partially eliminated by the process.

Table 2. Ether treatment of $A P P$ extract

\begin{tabular}{|c|c|c|c|c|c|c|}
\hline Sample & $E 260 \mathrm{~m} \mu$ & $E 280 \mathrm{~m} \mu$ & $\mathrm{E} 280 / E 2260$ & $\underset{\text { 'protein' }}{\text { CFT/ }}$ & $\underset{\text { titre }}{\text { CF }}$ & 'Protein' \\
\hline (o & 0.496 & 0.292 & 0.59 & 21 & 23 & $1 \cdot 1$ \\
\hline H (aqueous phase) & 0.403 & 0.210 & 0.52 & $1 \cdot 4$ & 0 & - \\
\hline C (from emulsion) & 0.065 & 0.044 & 0.63 & 1.8 & $6 \cdot 8$ & $\mathbf{3} \cdot \mathbf{3}$ \\
\hline
\end{tabular}

Table 3. Batch adsorption with hydroxyapatite

\begin{tabular}{|c|c|c|c|c|c|c|}
\hline $\begin{array}{l}\text { No. of } \\
\text { treatments }\end{array}$ & $E 260 \mathrm{~m} \mu$ & 'Protein' & CF titre & $\begin{array}{c}\text { CF recovery } \\
(\%)\end{array}$ & $\underset{\text { 'protein' }}{\text { CFT/ }}$ & $\begin{array}{c}\text { CFT/ } / \\
\text { E260 m } \mu\end{array}$ \\
\hline o & 0.875 & $32 \cdot 2$ & 58 & 100 & 1.8 & 66 \\
\hline 1 & not clear & $13 \cdot 2$ & 40 & 69 & 3.0 & - \\
\hline 2 & 0.56 & 4.9 & 82 & 55 & 6.5 & 57 \\
\hline 3 & 0.52 & $4 \cdot 0$ & 31 & 53 & $7 \cdot 7$ & 60 \\
\hline 4 & 0.46 & $2 \cdot 7$ & 26 & 45 & $9 \cdot 6$ & 57 \\
\hline 5 & 0.44 & $2 \cdot 8$ & 24 & 41 & $8 \cdot 6$ & 55 \\
\hline
\end{tabular}

\section{Adsorbents}

Calcium phosphate (brushite or hydroxyapatite) adsorbed the CF activity and part of the 'protein' from crude or APP extracts in $\mathrm{pH} 8.2$ phosphate buffers at concentrations less than about $0.09 \mathrm{~m}$. Much of the activity was eluted at $0.125 \mathrm{~m}$ concentration. Batch and chromatographic methods of purification used before the ccllulose ion exchangers were available were based on these observations.

Batch treatment. A suspension of hydroxyapatite $(15 \mathrm{ml}$.) was centrifuged and the packed deposit $(5.4 \mathrm{ml}$ ) washed three times with $0.125 \mathrm{M}$-phosphate $\mathrm{pH} 8.2$ by suspension and centrifuging. The adsorbent was finally resuspended in the buffer and the suspension distributed as evenly as possible between five centrifuge tubes. These werc centrifuged, the supernatant fluids removed and the tubes stoppered until required. An extract ( $32 \mathrm{ml}$. from 189 infected suckling mouse brains) which had been purified by two successive precipitations at $\mathrm{pH} 4.5$ was dialysed against $0 \cdot 125 \mathrm{M}$-phosphate pH 8.2, sampled and stirred for $30 \mathrm{~min}$. at $4^{\circ}$ in one of the centrifuge tubes containing the washed adsorbent. The mixture was centrifuged and the supernatant fluid was sampled and treated with fresh adsorbent in the same manner. Stirring, centrifuging, sampling and transference were repeated until the 
extract had received five adsorptions. The samples $(0.4 \mathrm{ml}$.) were diluted $1 / 20$ in BS, examined in the spectrophotometer, titrated and used for 'protein' estimation ('Table 3). The purity (CFT/ 'protein') was increased by a factor of 4.8 but substances absorbing at $260 \mathrm{~m} \mu$ were not selectively removed. The final supernatant fluid from this experiment was treated with ether as previously described, $87 \%$ of the CF activity being recovered. During the ether treatment there was a slight decline (to 6.1) in the purity calculated on 'protein' but the ratio CFT/E $260 \mathrm{~m} \mu$ was increased by a factor of 6 . 'This removal (in the aqueous phase) by the ether process of substances absorbing at $260 \mathrm{~m} \mu$ was not always observed but on some occasions the absorption pcak was changed from $260 \mathrm{~m} \mu$ to about $275 \mathrm{~m} \mu$.

Chromatography. In an experiment using stepwise elution with $\mathrm{pH} 8 \cdot 2$ phosphate buffers of inereasing concentration from $0.01 \mathrm{M}$ to $0.125 \mathrm{M}, 23 \%$ of the CF activity of an APP extract was recovered in two peaks corresponding to the $0.11 \mathrm{u}$ and $0 \cdot 125 \mathrm{M}$ levels. In the fractions of highest titre the purity (CFT/mg. $\mathrm{N} / \mathrm{ml}$.) was B.3 times that of the extract applied to the column.

Diethylaminoethyl (DEAE) cellulose. The antigen bchaved on this adsorbent (which formed more freely flowing columns than calcium phosphate and appeared to have a higher capacity) in a manner closely resembling its behaviour on calcium phosphate, but a higher salt concentration was needed for elution. A crude extract $(40 \mathrm{ml}$.) prepared from about 110 infected brains was dialysed against $0.005 \mathrm{M}$ phosphate pH 8.2 and applied to a column containing $10 \mathrm{~g}$. of buffer-cquilibrated DE $\Lambda$ E cellulose. Stepwise elution was carried out with $200 \mathrm{ml}$. volumes of phosphate mixtures at $\mathrm{pH} 8.2$ of $0.005,0.09$ and 0.125 molarity followed by $0.125 \mathrm{M}$-phosphate $+0 \cdot 1 \mathrm{~N}-\mathrm{NaCl}$ and finally a mixture $(\mathrm{pH} 6.0)$ of $\mathrm{Na}_{2} \mathrm{HPO}_{4}$ and $\mathrm{NaH}_{2} \mathrm{PO}_{4}$ molarity 0.1 with $\mathrm{NaCl} 0.5 \mathrm{M}$. The cmuent was collected in $5 \mathrm{ml}$. fractions. About half of the protein applied to the column appeared in the fraction eluted with $0.09 \mathrm{~m}$ buffer which, however, contained negligible $\mathrm{CF}$ activity. Fractions cluted with the two most concentrated buffers were assembled in pools which were analysed for 'protein' and CF activity. The total recovery of CF activity was $33 \%$ and the purity (CFT/'protein'), was about three times that of the crude extract. A mixture $(303 \mathrm{ml}$.) of the CF active pools from this experiment was dialysed bricfly against water, thoroughly against $0.005 \mathrm{M}$-phosphate $\mathrm{pHI} 8.2$ and applied to a column (13 mm. diam.) prepared from $1 \mathrm{~g}$. of equilibrated DFAE. Stcpwise elution was carried out (Fig. 3 ) and one hundred $2.5 \mathrm{ml}$. fractions were collected. The CF titre of the influent solution was 19.2 and that of the most active fraction 500. Of the 'protcin' applied $93 \%$ was recovered including $13 \%$ in the $\mathrm{NaOH}$ solution used to regencrate the adsorbent. Unfortunately $40 \%$ of the initial 'protcin' was associated with the fractions containing the CF activity so that the most active fractions were only about twice as 'pure' as the solution applied. The recovery of CF activity was about $40 \%$.

As the rather striking 'peaks' of protein concentration and $\mathrm{CF}$ activity were obviously artifacts attributable to the discontinuous increases in buffer concentration, linear-gradient elution was used in subsequent experiments. An extract. (74 $\mathrm{ml}$. CFT 278) which had been purificd by two precipitations at $\mathrm{pH} 4 \cdot 5$, was dialysed against $0.005 \mathrm{M}$-phosphate $\mathrm{pH} 8.2$ and applied to a column of DEAE cellulose $(2 \mathrm{~g}$.) equilibrated with this buffer. The column was rinsed with the $0.005 \mathrm{M}$ buffer until $89 \mathrm{ml}$. of filtrate containing a negligible amount of protein and no detect- 
able CF activity had bcen collected. Elution was continued with $0.09 \mathrm{M}$-phosphate pH 8.2 until nine $20 \mathrm{ml}$. fractions had been collected. Thereafter a linear gradient. prepared from $250 \mathrm{ml}$. of the $0.09 \mathrm{M}$ buffer and $250 \mathrm{ml}$. of $0.3 \mathrm{M}$-potassium phosphate mixture pH 6 was passed in and the effluent was collected in $20 \mathrm{ml}$. fractions. The results (Fig. 4) suggest that there may be four components having CF activity of which two are only very slightly separated. The recovery of CF activity was $60 \%$

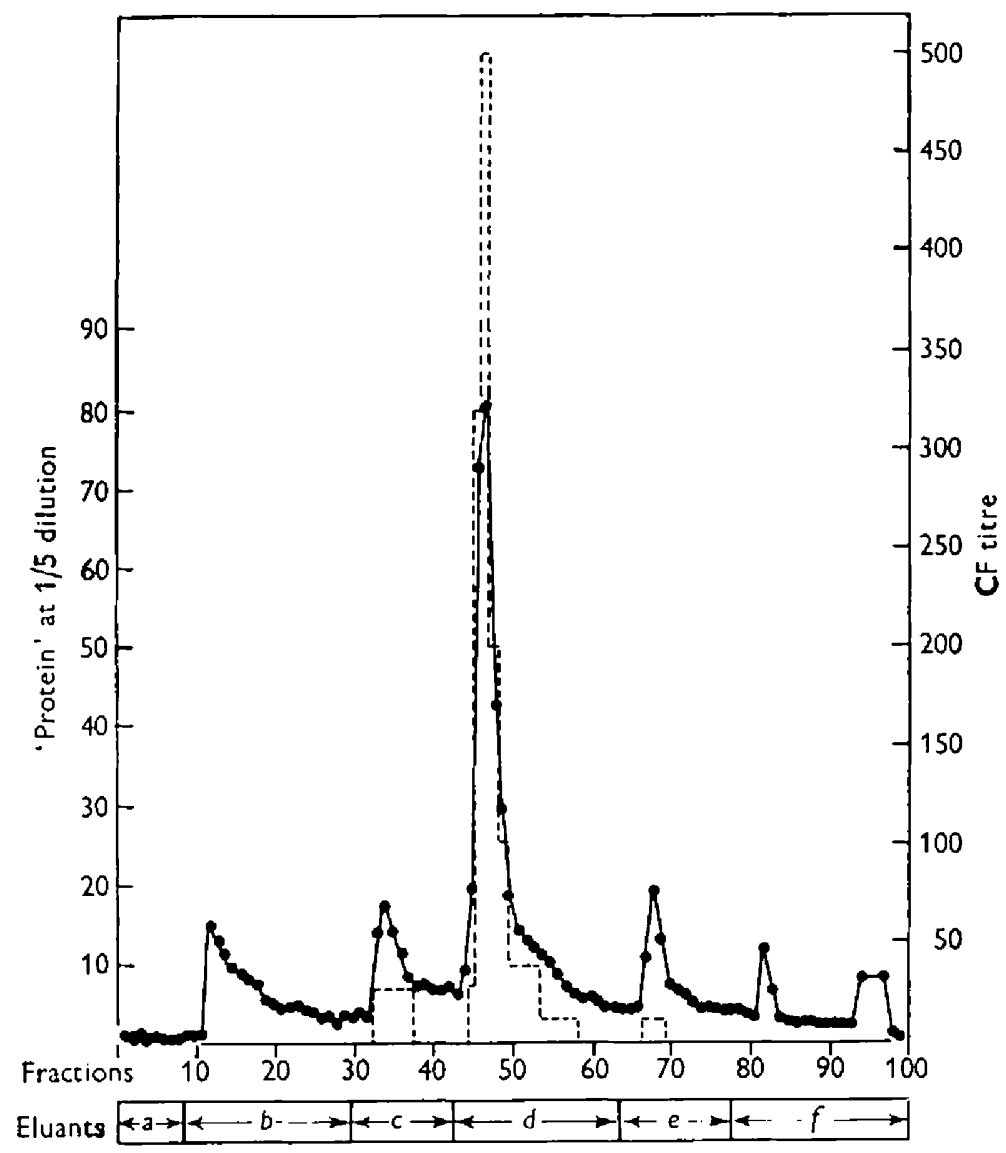

Fig. 3. Repeated chromatography on DEAE cellulose of CF-nctive fractions from the chromatography of a crude extract. Broken line, histogram of ( $F$ titres; full line 'protcin' concentrations. Ellution was stepwise with the following solutions: $(a) 0.005$ m-phosphate pH $8 \cdot 2 ;($ (l) $0 \cdot 09$ n-phosphate pH 8.2; (c) 0.125 M-phosphate pH 8.2; (d) 0.125 M-phusphate

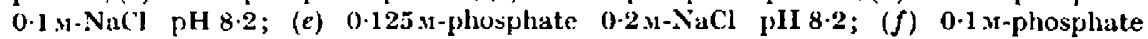
$0 \cdot 5 . \mathrm{M}-\mathrm{NaCl}$ pH 6 .

but the purity improvement factor (less than 2 in the main fraction) was disappointing. Fractions 1-6 were mixed to give pool $A$ and fractions 13-37 to give pool $B$. $20 \mathrm{ml}$. portions of $A$ and $\mathbf{B}$ were separately dialysed and freeze-dried. The residues, dissolved in very small volumes of CFT saline, werc applied to a micro-Ouchterlony plate with mouse anti-rabies serum VI and concentrated rabbit antinormal mouse brain $\gamma$-globulin as sources of antibody. 'The only lines of precipitation detected 
were one between $B$ and the mouse serum and two between $A$ and the rabbit $\gamma$-globulin. The remainder of $\mathbf{B}$, after dialysis against $0.005 \mathrm{M}$-phosphate $\mathrm{pH} 8.2$ occupied $390 \mathrm{ml}$. and had a CF titre of 50. This was applied to a column prepared from $2 \mathrm{~g}$. DEAE cellulose and followed first by $0.005 \mathrm{w}$ bulfer until two $20 \mathrm{ml}$. fractions had been collected and then by a lincar gradient prepared from $300 \mathrm{ml}$. $0.005 \mathrm{M}$ and $300 \mathrm{ml} .0 \cdot 3 \mathrm{M}$ buffers. The results (Fig. 5) confirmed that 2 or possibly $3 \mathrm{CF}$ active components may have been present in pool $\mathrm{B}$, but also indicated that most of the 'protein' was associated with the active fractions, making it seem unlikely that much further purification could be achieved by this process.

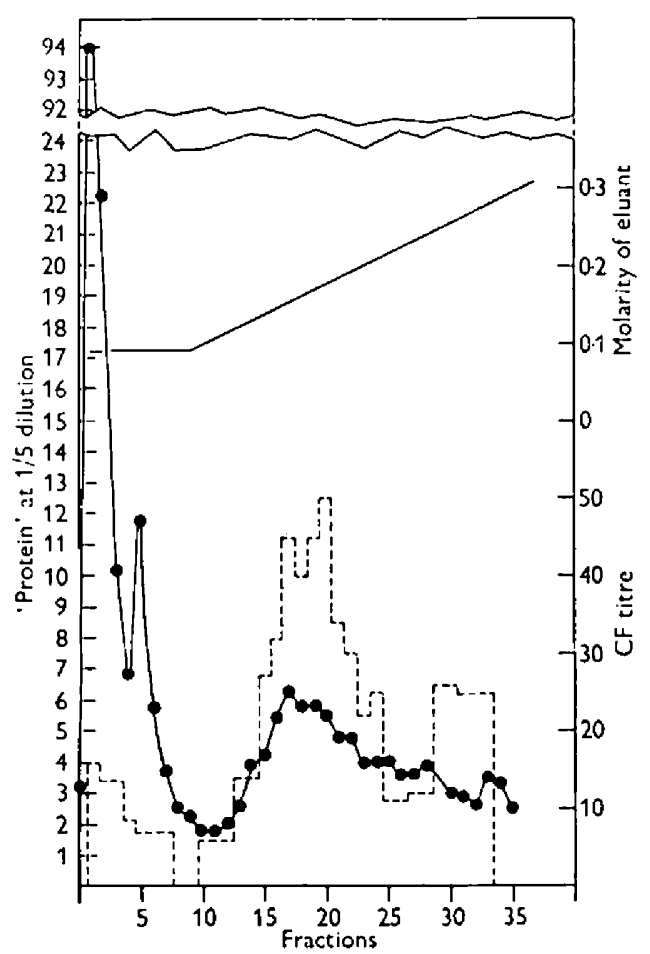

Fig. 4

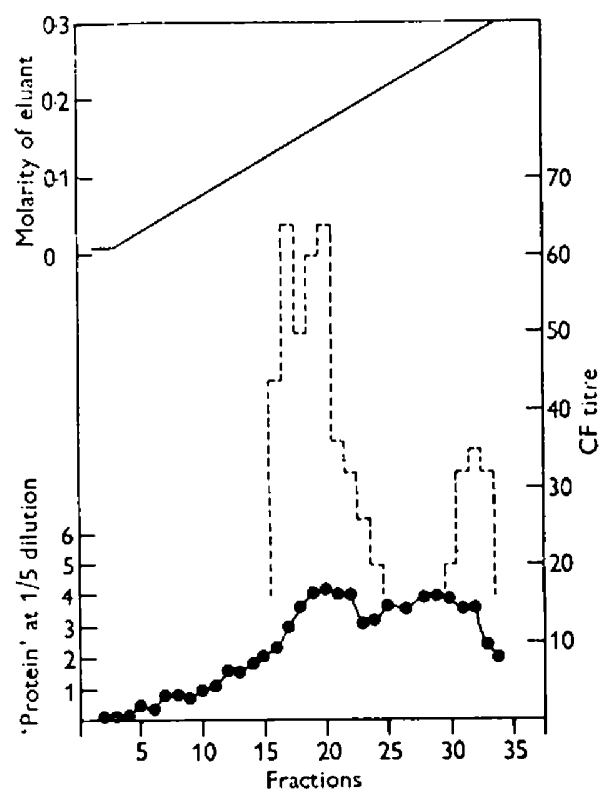

Fig. 5

Fig. 4. Chromatography of APP extract on DEAE cellulose with gradient clution. Broken line, listogram of CF titres; full line and circles, "protein' concentration; full line without points, clution gradient.

Fig. 5. Repeated chromatography of fractions 13-37 from the experiment shown in Fig. 4. I3roken line, histogram of 'Cl' titres; full line with circles, "protein' concentrations; pliain line, elution gradient.

Complement-fixing titrations are subject to so many possibilities of error that little importance was at first assigned to the twin peaks (at fractions 16 and 20 in Fig. 4 and fractions 17 and 20 in Fig. 5), but double peaks were later repeatedly observed and are probably significant. Fractions 18 (CFT 50) and 33 (CFT 32) were separately dialysed and dried from the frozen state. The residues dissolved in $0.05 \mathrm{ml}$. portions of CFT saline were applied to a micro-Ouchterlony plate with 
mouse rabies antiserum VI as source of antibody. Only fraction 33 reacted visibly and only one line of precipitate was detected.

Carboxymethylcellulose at the lowest pII (about 6 ) at which precipitation could be avoided failed to adsorb the $\mathrm{CF}$ activity.

\section{Electrophoresis}

Starch gel. As the starch gels employed by Smithies (1955) appeared to exert some fractionating effect in addition to that induced by electrophoresis, some of the earliest experiments were made by this technique in the hope that the relatively large antigen would be retained in or near the starting trough while other brain constituents would migrate into the gel. Although this was so, the method was abandoned in the hope that more convenient techniques capable of treating larger quantities of extract would be discovered. Starch gel electrophoresis did, however, confirm the expected complexity of the extracts. In one experiment cighteen bands were detected in a gel slice stained with naphthalene black.

Paper, glass fibre, and cellulose acetate strips. Attempts to control fractionation by paper elcetrophoresis of extracts before and after chromatography or other treatment were unsuccessful owing to adsorption by the paper. Stained electrophoresis strips usually revealed a narrow intense band at the starting line with a rather evenly stained tail in the direction of the positive electrode, the length of the tail being proportional to the amount of substance applicd. Similar results were obtaincd on glass fibre paper. Cellulose acetate strips (Kohn, 1957) gave better results; two major and about three minor peaks could be detected by a crude scanning photometer. There was, however, too much dilluse staining between these peaks for our purpose.

Agar. In experiments at $\mathrm{pH} 7 \cdot 6, \mathrm{pH} 8 \cdot 2$ and $\mathrm{pH} 8 \cdot 6$ crude extracts gave agar electrophoretograms in which 6-9 fractions could be detected; of these, 2 possessed grcater mobilities than the albumin fractions of human or mouse serum run simultancously. Traces of these components were also visible in the mouse scrum electrophoretogram. The most intense spots corresponded in position with haemoglobin and albumin. 'There was much 'tailing' on the negative side of the starting trough at pII $7 \cdot 6$ and on the positive side at $\mathrm{pH} 8 \cdot 6$. APP' extracts gave only a tail on the positive side in which no discrete fractions were detectable. This behaviour accords with the results of immunoelectrophoretic experiments (Mead, 1962).

Starch grains. A preliminary experiment indicated that neither the protein nor the CF activity of a chromatographically purified extract was adsorbed significantly by washed starch grains in $\mathrm{pH} 6 \cdot 2$ phosphate $(\mu=0 \cdot 05) .2 \mathrm{ml}$. each of fractions 46 and 48 (CFT originally $>200$ ) and about $1 \mathrm{ml}$. of fraction 47 (CFT originally 500) from the chromatography experiment described above (Fig. 3) were combined, dialysed and freeze dried. 'The residue was dissolved in $0.5 \mathrm{ml}$. $\mathrm{pH} 6.2$ phosphate $(\mu=0.05)$ and $0.4 \mathrm{ml}$. injected along the transverse centre line of a slab prepared from $80 \mathrm{~g}$. of washed, ethanol-extracted starch which had been washed twice with the bulfer and allowed to drain in the electrophoresis trough. Flcctrophoresis was continued for $4.5 \mathrm{hr}$. at $10 \mathrm{~V} . / \mathrm{cm}$. The current was $21.5-22 \mathrm{~mA}$. and the temperature of the cooling water $11^{\circ}-12 \cdot 5^{\circ}$. 'The positive end of the slab was cut into twentyfour $0.5 \mathrm{~cm}$. sections which were extracted with $5 \mathrm{ml}$. portions of buffer. Fractions were numbered from the origin and those numbered $8,11,13,15$ and 20 scparately 
titrated. Titrations were also made on pools made by mixing equal volumes of certain fractions. In the best fractions of the twice-chromatographed material there was much protcin closely resembling but not coincident with the antigen in mobility (Fig. 6), indicating that further purification by either method was unlikely to succeed.

Columns of modified cellulose. Electrophoresis experiments were done in the modified I, KB apparatus to cnsure maintenance of constant current and pII during long runs. In an experiment with crude extract (Fig. 7 ) in phosphate at $\mathrm{pH} 6 \cdot 0$

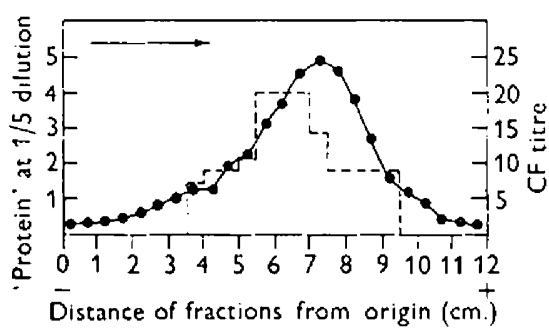

Fig. 6

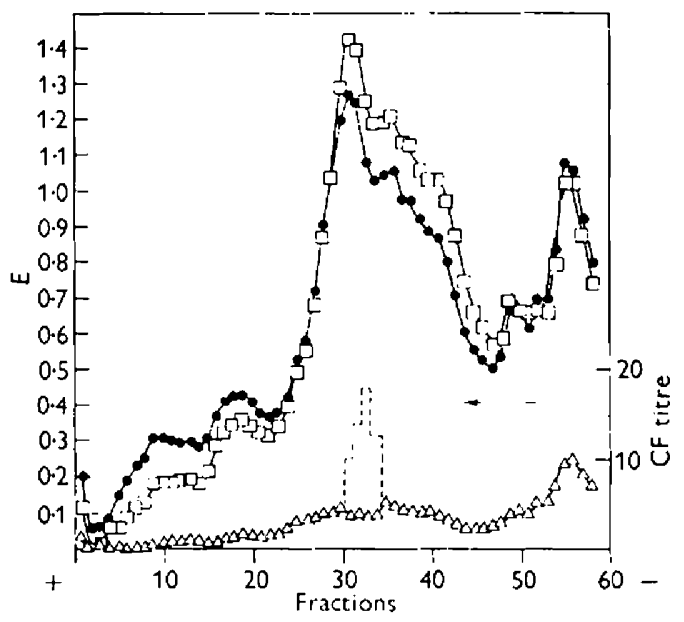

Fig. 7

Fig. 6. Electrophoresis, on starch grains, of the most active fractions from the rechromatography of crude extract on DEAE cellulose (Fig. 3). Broken line, histogram of CF titres; full line, 'protein' concentration. The arrow indicates the direction of migration.

Fig. 7. Electrophoresis of a crude extract in the L.K.B.-Produkter apparatus. - absorption of fractions at $260 \mathrm{~m} \mu$; $-[-$ absorption at $275 \mathrm{~m} \mu ;-\triangle-$ absorption at $540 \mathrm{n} \mu$; - - listogram of CF titres. The arrow indicates direction of migration. Absorption at $260 \mathrm{~m} \mu$ ("nucleotide') exceeded absorption at $275 \mathrm{~m} \mu$ ("protein ") in the first two peaks and even in the last which as indicuted by its colour and absorption at $540 \mathrm{~m} \mu$ was rich in haemoglobin or haemoglobin-like pigment. Separution of red pigment into several fractions was noticed also in chromatograms of crude extracts.

$(\mu=0 \cdot 1)$ only about $10 \%$ of the $\mathrm{CF}$ activity was recovered in a single rather sharp pcak with a mobility slightly less than that of the main u.v. (275 $\mathrm{m} \mu$ ) peak but containing a high proportion of the u.v. absorbing material applied to the column. Runs with APP extract were made at $\mathrm{pH} 5.95$ and 8.6 with recoveries of 13 and $36 \%$. In both runs the peak of CF activity emerged just on the low mobility side of the main protein peak, the separation appearing to be better at the lower pII. The best result was obtained with material purified as follows: $\mathbf{A}$ brain extract prepared by the Casals method (with chloroform + methanol extraction) was purified by precipitation at $\mathrm{pH} \mathbf{4 . 5}$ and refined by two batch treatments with calcium phosphate in $0.125 \mathrm{u}$-phosphate $\mathrm{pH} 8.2$. The refined extract $(30 \mathrm{ml}$.) was pervaporated, dialysed against water, again pervaporated and dialysed against the electrophoresis buffer (phosphate of $\mathrm{pH} 6.2$ and $\mu=0.1$ containing $0.01 \%(\mathrm{w} / \mathrm{v})$ each of 
'Triton X-100' and chloromycetin). 'The extract ( $3 \mathrm{ml}$. CF titre 2600) was applied to the column and displaced downwards with about $10 \mathrm{ml}$. of buffer. Flectrophoresis at $277-280 \mathrm{~V}, 45-46 \mathrm{~mA}$ and $8 \cdot 5^{\circ}-8 \cdot 7^{\circ}$, was maintained for $23 \mathrm{hr}$. The column fluid was displaced by buffer and collected in $3 \mathrm{ml}$. fractions which were diluted 1/10 with BS for 'protein' estimation. 'Those fractions giving a 'protein' reading exceeding about $0 \cdot 7$ were tested for $\mathrm{CF}$ activity at $1 / 10$ and those fixing complement

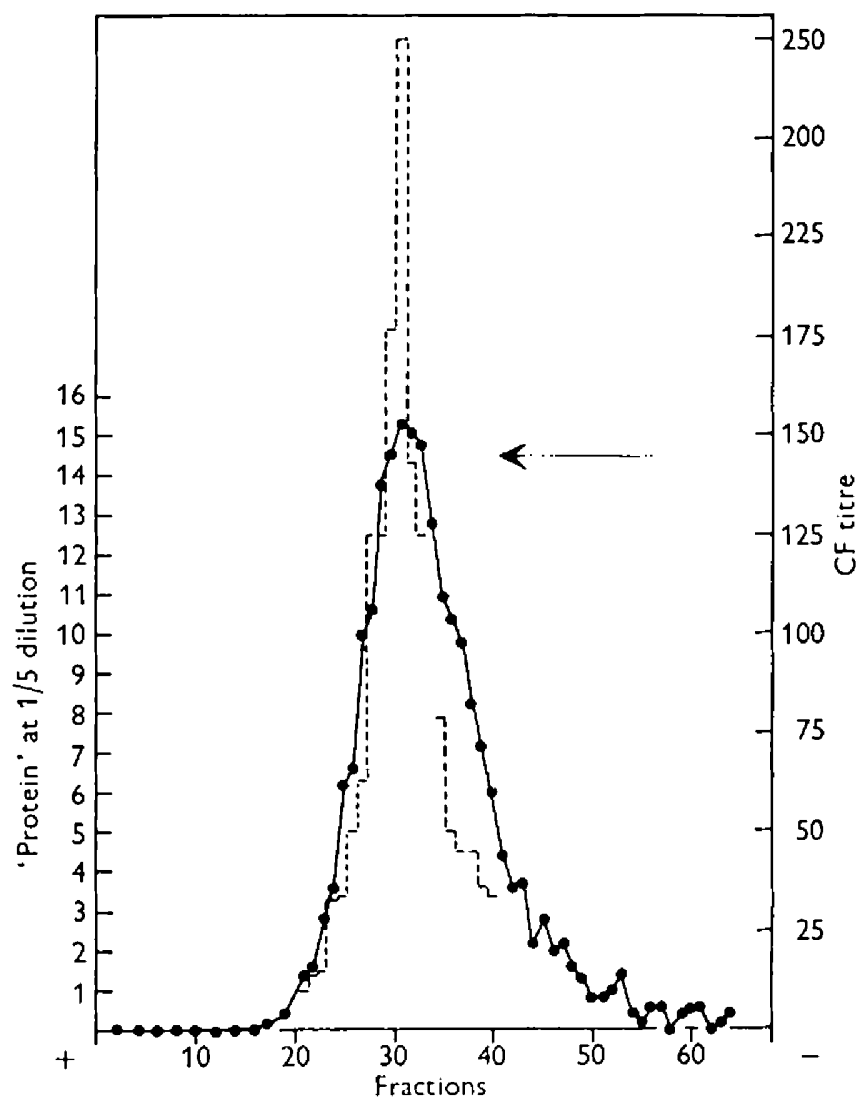

Fig. 8. Electrophoresis of purifed APP cxtract in the I..K.B.-Produkter apparatus. Broken line, histogram of CF titres (no value for fraction 34 was available); full line, protein concentrations. The arrow indicates the direction of migration.

at this dilution were titrated. The recovery of $\mathrm{CF}$ was about $60 \%$ but the purity of the best fraction was only about one and a half times that of the starting solution The mobilities of the CF activity and main protein component coincided closely (Fig. 8).

\section{Centrifugation}

At this time the antigen was thought to consist only of particles about $12 \mathrm{~m} \mu$ in diameter (Polson \& Wessels, 1953) which might bc expected to sediment slowly in the preparative ultracentrifuge. The purest available sample-fractions 22-40 from the column electrophoresis experiment described above (Fig. 8)-was dialysed 
against water, pervaporated and dialysed against buffered saline containing $0 \cdot 01 \mathrm{M}$ $\mathrm{Ca}^{++}$and $0.01 \mathrm{M}-\mathrm{Mg}^{++}$which were thought likely to promote aggregation. The solution $(2.8 \mathrm{ml}$.) was centrifuged $1 \mathrm{hr}$. at $6600 \mathrm{~g}$ in the No. 40 rotor yiclding a clear supernatant fluid and a small pellet which was resuspended in $2.8 \mathrm{ml}$. of the buffer (fraction $\mathbf{A}$ ). The supernatant fluid was placed in a clean tube, overlaid with the buffer to a total volume of $10 \mathrm{ml}$. and centrifuged in the No. 40 rotor for $5 \mathrm{hr}$. at $63,000 \mathrm{~g}$ to yield a supernatant fraction (B) and a small pellet which was resuspended in $1 \mathrm{ml}$. of the bufer (C). The three fractions were tested for $\mathrm{CF}$ titre and 'protein ' content. Of the CF activity recovered, $86 \%$ remained in supernatant $\mathrm{B}$ and $14 \%$ was in the pellet (C). Of the initial 'protein' $2 \%$ appeared in $\mathrm{A}, 8.4 \%$ in $\mathrm{B}$ and $14 \%$ in $\mathrm{C}$. Neither the expected sedimentation of antigen nor any separation of antigen from 'protein' was accomplished. In a similar experiment, APP cxtract after' clarification at $6600 \mathrm{~g}$ was spun for $6 \mathrm{hr}$. at $70,000 \mathrm{~g}$ in the S.W. 39 rotor. The pellet contained $15 \%$ of the initial CF activity and $17 \%$ of the initial 'protein'.

\section{Miscellaneous experiments}

CF activity did not appear to be precipitable by streptomycin, a reagent which has been used to purify nucleoprotein particles from a variety of sources (Cohen, 1947; Takata \& Osawa, 1957). Four portions of a solution of APP extract were treated with graded amounts of a solution of salmine sulphate while a fifth portion served as control. The mixtures, except the control, contained precipitates and after a night at $4^{\circ}$ were centrifuged. The supernatant fluids were titrated for $\mathrm{CF}$ activity which was found to have been reduced (finally to $18 \%$ ) in proportion to the amount of protamine added. In confirmation of van den Ende et al. (1957), it was found that only part of the $\mathrm{CF}$ activity of extracts was destroyed by digastion with crystalline trypsin at a concentration of $0.2 \mathrm{mg} . / \mathrm{ml} ., \mathrm{pH} 8.2$ at $37^{\circ}$ for $30-50 \mathrm{~min}$.

\section{Extracts of normal mouse brains}

Several batches of brains from uninfected mice 7-8 days old were extracted and the extracts subjected on various occasions to dialysis precipitation, acid precipitation, calcium phosphate refining, ether treatment and electrophoresis on ccllulose acetate strips. Fixtracts from normal brains (diluted 1/10) did not fix complement in the presence of mouse anti-rabies serum and, except at one of several identical locations in each of two very early experiments, formed no lines of precipitation with this serum in the Ouchterlony test. The elution diagram (from DFAF cellulose) of the protein in the supernatant fluid from pII 4.5 precipitation of normal brain extracts differed slightly from those obtained with pII 4.5 supernatant fluids from infected brains. Otherwise no obvious difference was detected between the behaviour of extracts of normal or infected brains in any of the procedures mentioned.

\section{DISCUSSION}

It was not anticipated that purification of the rabies soluble antigen discovered by Polson \& Wessels (1953) would be easy. The failure of previous workers to obtain a positive gel precipitin test suggested that the concentration of antigen was small, and the complexity of the tissue extracts implied that specific immunological methods of purification might be needed. It secmed best, however, to remove as 
much of the irrelevant brain constituents as possible before attempting purification by specific precipitation. During this preliminary work it was noticed that the complement-fixing components in the brain extracts were unstable and readily adsorbed by precipitates. In attempts at deprotcinization by standard methods the CF activity was taken out in the protein fraction but could sometimes be recovered therefrom with its purity improved.

The most effective initial step appeared to be precipitation at pH 4.5 . This involved a loss of $50-75 \%$ of the $\mathrm{CF}$ activity but the product was more stable. No method of purification with a yield greater than about $50 \%$ was discovered and it was difficult to increase the purity ratio CF activity/concentration of impurities because the numerator diminished during manipulations and short periods of storage about as quickly as the denominator could be reduced by chemical or physical operations.

Batch adsorption of impurities from APP extracts on calcium phosphate under conditions (of buffer concentration) in which CF activity remained in the supernatant fluid, was a fairly eflicient method of purification; the product gave a single electrophoresis peak coincident with the CF activity (Fig. 8). Chromatography on calcium phosphate or DEAE cellulose was also uscful. Electrophoresis of erude and APP extracts without prior treatment with adsorbents gave pcaks of CF activity overlapped by, but not coincident with, a major protein peak (Fig. 7). The protein remaining after treatment with calcium phosphate resembled the $\mathrm{CF}$ activity so closely in its electrophoretic behaviour that further purification by methods depending on surface charge seemed likely to prove diflicult. Much of the impurity resembling nucleic acid in its u.v. absorption could sometimes be eliminated by treatment with ether when the $\mathrm{CF}$ activity entered the gol and the nucleic acidlike impuritics remained in the aqueous phase.

The purity of the best samples prepared by these methods was only from two to three up to about ten times that of the crude extract. The absence of visible interaction in the Ouchterlony test between some of the purified fractions and antinormal mouse brain $\gamma$-globulin is attributed rather to the poor antigenic response of the immunized rabbits than to the purity of the rabies antigen.

The author is grateful to Miss I. Staarmann for excellent technical assistance, to Mr G. S. Turner for the neutralization test, to $\mathbf{M r ~ W}$. II. Borret and Mr K. J. Kaufman for making the fraction collectors and other apparatus, and to his colleagues in the Virus Unit for valuable advice.

\section{REFERENCES}

CAsuıs, J. (19.19). Acetone-ether extracted antigens for complement fixation with certain neurotropic viruses. Proc. Soc. exp. Biol., N.Y. 70, 339.

Casals, J. \& Olitsky, P. K. (19:50). A complement-fixation test for poliomyelitis virus. Proc. Soc. exp. Biol., N.Y. 75, 315.

Сонl: , S. S. (1947). Streptomycin and desoxyribonuclease in the study of variations in the properties of a bacterial virus. J. biol. Chem. 168, 511 .

Dusbicc:o, R. \& Vocr, M. (1954). Plaque formation and isolation of pure lines with poliomyclitis viruses. J. exp. Med. 99, 2.

Fiodis, P. \& Kupki, D. W. (1956). Zone electrophoresis on cellulose columns. Biochim. biophys. Acta, 21,368 . 
Flynn, F. V. \& DE Mayo, P. (195̃1). Micro-electrophoresis of protein on filter paper. Lancet, ii, 235.

Grabar, P. \& Williams, C. A. Jun. (1955). Méthode immuno-électrophorétique d'analyse des mélanges de substances antigéniques. Biochim. biophys. Acta, 17, 67.

Kons, J. (1957). A cellulose acetate supporting medium for zone electrophoresis. Clin. chim. Acta, 2, 298.

Конк, J. (1958). Small scale membrane filter electrophoresis and immuno-electrophoresis. Clin. chim. Acta, 3, 450.

Koнs, J. (1959). $\Lambda$ simple method for the concentration of fluids containing protein. Nature, Lond. 183, 1055 .

Mayfi, M. M., Osler, A. G., Bier, O. \& Heidelberger, M. (1946). The activating effect of magnesium and other cations on the hacmolytic function of complement. $J$. exp. Med. 84, 535.

McKenzie, H. A. \& Wal.tACE, II. S. (1954). The Kjeldahl determination of nitrogen: $\Lambda$ critical study of digestion conditions-temperature, catalyst and oxidizing agent. Aust. J. Chem. 7, 55.

MEAD, T. H. (1962). The characterization of rabies soluble antigens. J. gen. Microbiol. $27,415$.

Oster, G. (1950). Two phase formation in solutions of Tobacco Mosaic Virus and the problem of long range forces. J. gen. Physiol. 33, 445.

PAIGEN, K. (1956). Convenient starch electrophoresis apparatus. Analyt. Chem. 28, 284.

PARR, C. W. (1954). The separation of sugars and of sugar phosphates by gradient elution from ion-exchange columns. Biochem. J.56, xxvii.

Petenson, E. A. \& Sobek, H. A. (1956). Chromatography of proteins. I. Cellulose ionexchange adsorbents. J. Amer. chem. Soc. 78, 751.

Polson, A. \& Wessins, P. (1953). Particle size of soluble antigen of rabies virus. Proc. Soc. exp. Biol., N.Y. 84, 317.

Ронатн, J. (1957). Some cellulose ion exchangers of low substitution and their chromatographic application. Ark. Kemi, 11,97.

SснӓғкR, W. \& Musк, K. (1952). Reinigung und Eigenschaften eines löslichen Antigens der klassisehen Geflügelpest. Z. Naturf. 7b, 573 .

Schfidfagr, J. J. (1955). Lne microméthode de l'immuno-électrophorése, Int. Arch. Allergy, Basel, 7, 103.

Smrthirs, O. (1955). Zone electrophoresis in starch grels: Group variations in the serum proteins of normal hurnan adults. Biochem. J. 61, 629 .

Takata, K. \& Osawa, S. (1957). Ribonucleoprotein from rabbit appendix microsomes. Biochim. biophys. Acta, 24, 207.

Tiselius, A. (1954). Chromatography of proteins on ealcium phosphate columns. Ark. Kemi, 7, 443.

Tisetius, A., HJertén, S. \& Levis, Ö. (1950). P'rotein chromatography on calcium phosphate columns. Arch. Biochem. Biophys. 65, 132.

Uritr., J. \& Grabar, P. (1956). Emploi de colorants dans l'analyse électrophorétique et immunoélectrophorétique en milieu gélifié. Ann. Inst. I'astêr. 90, 427.

van den Exde, M., Polson, A. \& Ternek, G. S. (1957). Experiments with the soluble antigen of rabies in suckling mouse brains. J. Hyg., Camb. 55, 331. 